\title{
RATIONAL DRUG USE TO INCREASE SERVICE QUALITY IN DEVELOPING COUNTRIES: A SYSTEMATIC REVIEW
}

\author{
Yuliana Helena Elisabeth, Vetty Yulianty Permanasari
}

Hospital Administration Program, Faculty of Public of Health, Universitas Indonesia

\begin{abstract}
Background: Rational drug use (RDU) generally covers appropriate prescribing, appropriate dispensing and appropriate patient use of medicines for the diagnosis, prevention, mitigation and treatment of diseases. To enhance RDU, the patient should receive medicines appropriate to their heath care conditions, at optimum doses and sufficient time, as well as at the cost that the individual and the community can afford. This study aimed to review systematically the rational drug use to increase service quality in developing countries.

Subjects and Method: A systematic review was conducted by searching the following databases included PubMed, Proquest and Garuda which published articles in last ten years. The keywords for this review included rational drug use, irrational drug use, drug use pattern, WHO indicator, hospital, developing country, and cross sectional. The inclusion criteria were review, systematic review, clinical review and guidelines. After review process 13 articles were included in this review.

Results: The average prescription was varying in several development countries included India, Ethiopia, Jordan, Pakistan, Indonesia, and Sri Lanka. The highest average prescription generic drug was in Ethiopia (90.61\%) and lowest was in India (25.37\%). The average prescription antibiotics highest was in Ethiopia (58.1\%) and lowest was in Indonesia (36\%). The percentage of injection prescriptions that exceed WHO recommendations occurs in Ethiopia (38.1\%). Percentage of compliance with the List of Essential Medicines highest was in India (74.3\%), and Sri Lanka (100\%). Prescriptions were adequately labeled highest was in Pakistan (100\%) otherwise lowest was in Ethiopia (45.4\%). Patients know about the dosage of the prescription highest was in Ethiopia (78.8\%) and Pakistan (61.6\%). All of the hospitals included in the study used the national drug list, formulary and standard treatment guidelines but none of them had their own drug list or guideline.

Conclusion: Rational drug use in several countries is slightly above the WHO recommendation. An intervention strategy includes managerial, educational, regulatory and economical strategies should be designed to solve the problem on the health care system in general.
\end{abstract}

Keywords: rational drug use, prescription, WHO, developing countries.

\section{Correspondence:}

Yuliana Helena Elisabeth. Hospital Administration Program, Faculty of Public of Health, Universitas Indonesia. Email: yuliana.helena@gmail.com.

Mobile: 081289691597.

BACKGROUND
Rational use of drugs is the key to
developing an effective and efficient
health care system. However, irrati-
onal use of drugs often occurs in deve-
loping countries because of prescrip-

tion, preparation, and delivery of irrational drugs. Good prescription practice is an important part of rational drug use (Menik et al., 2011).

According to Republic of Indonesia Law No. 36 of 2009 concerning 
Health, drug use must be done rationally. The conference of experts on rational drug use organized by WHO in Nairobi in 1985 stated that the use of drugs was declared rational if patients received drugs according to clinical needs, in doses that matched individual needs, inadequate time periods and at affordable prices for patients and society. The aim is to be costeffective, facilitate access for the people to get drugs, prevent the use of inappropriate drugs, and increase patient trust in the quality of health services.

The effect of drugs that are used irrationally is the increase of morbidity and mortality; the decrease of drug availability and waste on medical expenses; the increase of side effects and unwanted reactions, such as bacterial resistance; and the psychosocial impact of unnecessary drug dependence (Ministry of Health, 2011). Furthermore, patient trust in the health care system has declined. In developing countries, this problem is exacerbated by limited resources and inadequate drug policies (Atif et al., 2016). In fact, the WHO estimates that more than half of all drugs in the world are prescribed, given and sold in an improper way and half of the patients use drugs inappropriately.

In 1993, the WHO issued a guide to drug use indicators aimed at measuring specific aspects of the behavior of healthcare providers in reproducible health facilities. This indicator consists of three; namely indicators of prescribing practices, key elements of patient care and availability of specific factors. Prescribing indicators include the average number of drugs per prescription, the percentage of drugs prescribed with generic names, the percentage of prescriptions with antibiotics, the percentage of prescriptions by injection and the percentage of prescribed drugs from the list of essential drugs or formularies. The patient service indicator consistsed of the average consultation time, the average time of preparation of the drug, the percentage of the right drug given, the percentage of the drug that was adequately labeled and the patient knowledge of the appropriate dose. While indicators of health facilities are the availability of a list of essential drugs or formulary and the availability of important drugs (WHO, 1993). WHO indicators are one of the widely accepted measurement tools for identifying and analyzing prescribing practices in health facilities (Vaishnavi et al., 2017).

Essential drugs are drugs that meet the health service needs of the majority of the population. Therefore essential drugs must be available at all times, in sufficient quantities and in suitable dosage forms. This concept along with rational use of drugs has a positive impact on drugs on health status, especially in developing countries (Desalegn, 2013). Doctors can only treat patients rationally if essential medicines are always available. One way to indicate the availability of essential drugs is to identify a short list of specific drugs that are important to treat general health problems and check the availability of these drugs in hospitals during the survey (WHO, 1993).

Monitoring routine prescribing patterns is important to monitor rati- 
onal drug prescribing in order to achieve better therapeutic results, thereby it increases patient satisfaction and quality of health services. Evaluation of drug use is done to check whether the drug is prescribed appropriately (Desalegn, 2013). The drug delivery system in health facilities needs to be evaluated to improve, especially, the efficiency of administration, availability of drugs and quality of labeling (Hettihewa et al., 2011).

The aim of this systematic review is to review and compare patterns of drug use in hospitals in several developing countries, namely Indonesia, India, Pakistan, Sri Lanka, Ethiopia, and Jordan, using WHO drug use indicators.

\section{SUBJECTS AND METHOD \\ 1. Study Design}

This was a systematic review using the PRISMA method. Literature search is done using three databases, namely Proquest, PubMed, and Garuda Ristekdikti. The keywords used in Indonesian and English are rational drug use, drug use patterns, WHO indicators, hospitals, developing countries and cross-sectional studies.
Searching with the Garuda Ristekdikti database using the keywords "rational drug use (title)" resulted in 23 articles after applying the criteria obtained 1 article. Searching with $\mathrm{Pu}-$ bmed databases using keywords (rational drug use) OR irrational drug use) AND drug use pattern (title/ abstract) produces 15 articles. After limiting the study, the search resulted in 5 articles. A literature search using Proquest database with keywords (rational drug use) AND (irrational drug use) AND (drug use pattern) AND ab (WHO indicator) AND ab (hospital) produce 36 articles after the application of criteria obtained 7 articles.

\section{Criteria for inclusion and exclusion}

A literature search was limited to studies with cross-sectional study designs published in the past ten years, both in English and Indonesian, and articles can be accessed in full. Literature used was studies conducted in developing country hospitals. The indicator used to assess drug rationality is an indicator issued by the WHO in 1993. The literature search process produced 13 articles. 


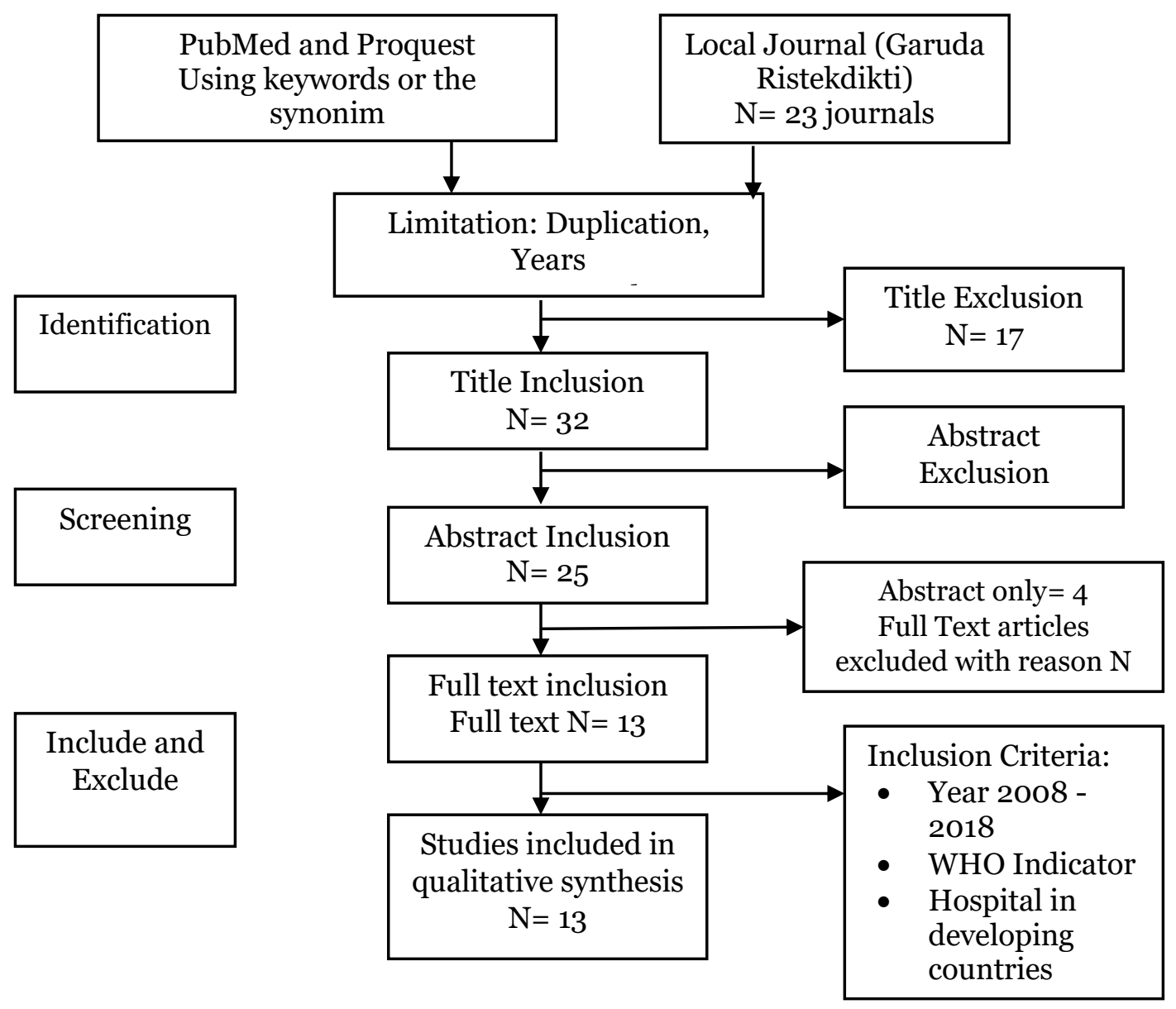

Figure 1. Flowchart with PRISMA method

\section{RESULTS \\ 1. Prescribing indicators}

The highest number of prescribed drugs per patient was found in India (5.5), while the least was in Ethiopia (1.9). The average number of drugs per prescription in Ethiopia is still acceptable as ideal when compared to the standard. In other countries, the average number of drugs per patient exceeds WHO recommendations (Table 1).

Of the 6 countries reviewed, the highest percentage of prescribed drugs in Ethiopia (98.7\%) was found while the lowest was in India (11.3\%). The percentage of generic drug use in
Indonesia is $85.39 \%$, Sri Lanka $71^{-}$ 78\%, Jordan 57.6\%, and Pakistan $56.6 \%$. The lowest percentage of recipes containing antibiotics in Jordan is $17.7 \%$ and the highest in Pakistan (82.3\%).

The percentage of prescriptions with antibiotics in Southern Ethiopia is $58.1 \%$, Indonesia $36 \%$, and India $22.66 \%$. The percentage of prescriptions with injections that exceed WHO recommendations is found in Ethiopia (38.1\%). In other countries, the percentage of prescriptions by injecttion is in accordance with WHO recommendation or below, as in Jordan $8.1 \%$. 
The highest percentage of drugs prescribed from the List of Essential Medicines (DOE) or formulary in Sri Lanka (100\%) followed by Indonesia (99.81\%) and Jordan 99.8\%. The per- centage of compliance with the List of National Essential Medicines (DOEN) in India was 74.30\%, Ethiopia 96.6\%, and Pakistan $98.8 \%$.

\section{Table 1. Core drug use indicators and their optimal values}

\begin{tabular}{lc}
\hline Core drug use indicators & Optimal values \\
\hline Prescribing Indicators & 1.6 to 1.8 \\
The average number of drugs per encounter & $100 \%$ \\
Percentage of drugs prescribed by generic name & 20 to $26.8 \%$ \\
Percentage of encounters with an antibiotic prescribed & 13.4 to $24.1 \%$ \\
Percentage of encounters with an injection prescribed & $100 \%$ \\
Percentage of drugs prescribed from EDL or formulary & \\
Patient Care Indicators & $\geq 10$ \\
Average consultation time (minutes) & $\geq 90$ \\
Average dispensing time (seconds) & $100 \%$ \\
Percentage of drugs actually dispensed & $100 \%$ \\
Percentage of drugs adequately labeled & $100 \%$ \\
Patients' knowledge of correct dosage & \\
Health Facility Indicators & $100 \%$ \\
Availability of copy of EDL or formulary & $100 \%$ \\
Availability of key drugs &
\end{tabular}

\section{Patient care indicators}

Ethiopia has the longest average consultation time of 4.7 minutes. One hospital in Sri Lanka has the shortest average consultation time of only 0.83 minutes. Meanwhile, the average consultation time in Pakistan is 1.2 minutes. The longest median preparation time in Ethiopia is 119.1 seconds and the fastest in Pakistan is 8.7 seconds. In one Sri Lankan hospital, the average preparation time for the drug was 69.36 seconds.

The percentage of the correct drugs given in accordance with WHO recommendations are in one hospital in Sri Lanka (100\%). In Pakistan, the percentage of the correct drugs was prepared at $97.3 \%$ while in Ethiopia $75.77 \%$. Of the drugs given, $45.4 \%$ of the drugs were adequately labeled in Ethiopia. In Sri Lanka, the drug labeled adequately is $\mathbf{1 9 . 3 8 \%}$. Even in one
Source: Desalegn, 2013; Atif et al., 2016 hospital, only $1.57 \%$ of drugs are labeled appropriately. These drugs are prepared without a medication schedule, amount, concentration, and pharmacy name. Recipes that are adequately labeled are the most in Pakistan (100\%).

The patients who knew the most information about the drugs given in Sri Lanka (100\%) followed Ethiopia by $78.8 \%$. The percentage of patients who understand the drug dose in $\mathrm{Pa}-$ kistan is $61.6 \%$.

\section{Health Facility Indicators}

Hospitals in Pakistan already have DOE copies, while some hospitals in southern Ethiopia have not kept a copy of the Ethiopian Essential Medicine List. Based on study several hospitals in eastern Ethiopia have used DOEN, national formulary, and standard treatment guidelines but do not yet have DOE, formulary and 
standard hospital treatment guidelines. Only 1 hospital in Pakistan has its own formulary but does not yet have standard treatment guidelines for infectious diseases.
In Ethiopia, the availability of essential drugs in hospitals is $65.7 \%$ and in Pakistan 72.4\%. The percentage of important antibiotic drugs available in stock in Pakistan is 93.8\%.

Table 2. Selected publication articles via PRISMA method

\begin{tabular}{|c|c|c|c|c|}
\hline Author & Title & $\begin{array}{l}\text { Prescribing } \\
\text { indicators }\end{array}$ & $\begin{array}{c}\text { Patient-care } \\
\text { indicators }\end{array}$ & $\begin{array}{c}\text { Facility- } \\
\text { specific } \\
\text { indicators }\end{array}$ \\
\hline $\begin{array}{l}\text { Hamsidi et } \\
\text { al. (2015) }\end{array}$ & $\begin{array}{l}\text { Evaluation of the } \\
\text { rationality of drug use } \\
\text { in terms of the } \\
\text { prescribing indicators } \\
\text { of the WHO in out pa- } \\
\text { tient patients in inter- } \\
\text { nal medicine for the } \\
\text { period of January- } \\
\text { June } 2015 \text { at the Bah- } \\
\text { teramas General } \\
\text { Hospital in Southeast } \\
\text { Sulawesi Province } \\
\text { (Indonesia) }\end{array}$ & 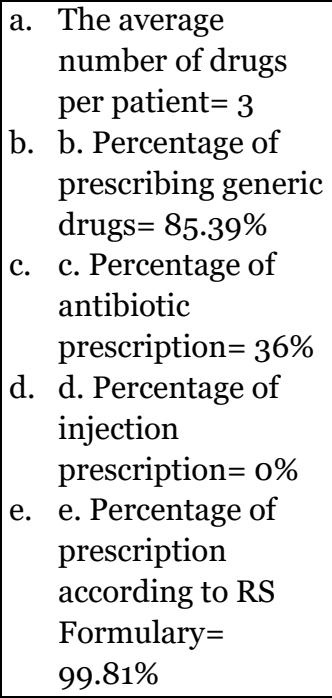 & & \\
\hline $\begin{array}{l}\text { Varakantha } \\
\text { m et al. } \\
(2018)\end{array}$ & $\begin{array}{l}\text { Antihypertensive } \\
\text { Prescription Pattern } \\
\text { and Compliance to } \\
\text { JNC } 7 \text { and JNC } 8 \text { at } \\
\text { Tertiary Care Gover- } \\
\text { nment Hospital, } \\
\text { Hyderabad, India: A } \\
\text { Cross-sectional } \\
\text { Retrospective Study }\end{array}$ & 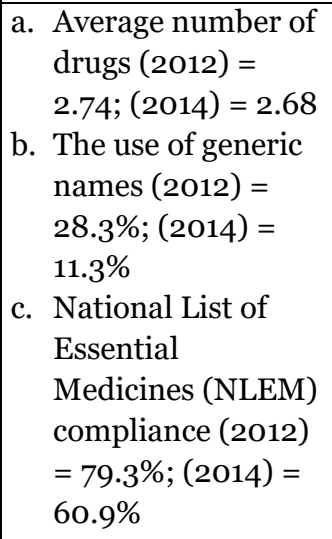 & & \\
\hline $\begin{array}{l}\text { Vaishnavi et } \\
\text { al. (2017) }\end{array}$ & $\begin{array}{l}\text { Assessment of } \\
\text { nonsteroidal anti- } \\
\text { inflammatory drug } \\
\text { use pattern using } \\
\text { World Health Orga- } \\
\text { nization indicators: A } \\
\text { cross-sectional study } \\
\text { in tertiary care teach- } \\
\text { ing hospital of Chhat- } \\
\text { tisgarh (India) }\end{array}$ & $\begin{array}{l}\text { a. The average } \\
\text { number of drugs } \\
\text { per prescriptions = } \\
3.15 \\
\text { b. The frequency of } \\
\text { prescription of } \\
\text { injection from } \\
\text { NSAID= 4.32\% } \\
\text { c. The percentage of } \\
\text { NSAIDs prescribed } \\
\text { with generic names } \\
=91.15 \% \\
\text { d. Prescriptions of }\end{array}$ & & \\
\hline
\end{tabular}




\begin{tabular}{|c|c|c|c|c|}
\hline Author & Title & $\begin{array}{l}\text { Prescribing } \\
\text { indicators }\end{array}$ & $\begin{array}{c}\text { Patient-care } \\
\text { indicators }\end{array}$ & $\begin{array}{c}\text { Facility- } \\
\text { specific } \\
\text { indicators }\end{array}$ \\
\hline & & $\begin{array}{l}\text { NSAIDs listed in } \\
\text { NLEM-2015 = } \\
49.72 \%\end{array}$ & & \\
\hline $\begin{array}{l}\text { Menik et al. } \\
\text { (2011) }\end{array}$ & $\begin{array}{l}\text { A survey: Precepts } \\
\text { and practices in drug } \\
\text { use indicators at } \\
\text { Government } \\
\text { Healthcare Facilities: } \\
\text { A Hospital-based pro- } \\
\text { spective analysis (Sri } \\
\text { Lanka) }\end{array}$ & $\begin{array}{l}\text { a. Average number of } \\
\text { drugs per } \\
\text { encounter }(\mathrm{TH})= \\
3.24,(\mathrm{GH})=2.88, \\
\text { and }(\mathrm{DH})=3.26 \\
\text { b. } \text { Percentage of } \\
\text { drugs prescribed } \\
\text { by generic name } \\
\text { (TH) }=78 \%,(\mathrm{GH}) \\
78 \%, \text { and }(\mathrm{DH})= \\
71 \% \\
\text { c. The percentage of } \\
\text { antibiotics }(\mathrm{TH})= \\
47 \% \text { in, }(\mathrm{GH})= \\
46 \% \text { in and }(\mathrm{DH}) \\
80 \% \\
\text { d. Percentage of } \\
\text { injections }(\mathrm{TH})= \\
3 \%,(\mathrm{GH})=4 \%, \\
\text { and (DH) } 6 \% \\
\text { e. The percentages of } \\
\text { drugs prescribed } \\
\text { from the essential } \\
\text { drugs list or formu- } \\
\text { lary (TH) = 97\%, } \\
\text { (GH) = 10o\%, and } \\
\text { (DH) = 99\% }\end{array}$ & \begin{tabular}{|ll} 
a. & Average con- \\
& sultation time \\
& $(\mathrm{TH})=2.31$ \\
& $\mathrm{~min},(\mathrm{GH})=$ \\
& $2.17 \mathrm{~min},(\mathrm{DH})$ \\
& $=0.83 \mathrm{~min}$
\end{tabular} & \\
\hline $\begin{array}{l}\text { Hettihewa et } \\
\text { al. (2011) }\end{array}$ & $\begin{array}{l}\text { Prospective } \\
\text { encounter study of } \\
\text { the degree of adhe- } \\
\text { rence to patient care } \\
\text { indicators related to } \\
\text { drug dispensing in } \\
\text { Health Care facilities: } \\
\text { A Sri Lankan pers- } \\
\text { pective }\end{array}$ & & $\begin{array}{l}\text { a. Average } \\
\text { dispensing time } \\
\text { o.18 min in TH, } \\
1.069 \text { min in GH } \\
\text { and } 1.156 \text { min in } \\
\text { DH } \\
\text { b. Percentage of } \\
\text { drugs actually } \\
\text { dispensed } \\
\text { 94.64\% in TH, } \\
79 \% \text { in GH and } \\
\text { 100\% in DH } \\
\text { c. Percentage of } \\
\text { drugs adequately } \\
\text { labeled } 22.16 \% \\
\text { in TH, } 17.57 \% \text { in } \\
\text { GH and } 1.57 \% \text { in } \\
\text { DH } \\
\text { d. Patient's know- } \\
\text { ledge on correct } \\
\text { dosage } 50 \% \text { in } \\
\text { TH, 100\% in GH } \\
\text { and o\% in DH }\end{array}$ & \\
\hline
\end{tabular}




\begin{tabular}{|c|c|c|c|c|}
\hline Author & Title & $\begin{array}{l}\text { Prescribing } \\
\text { indicators }\end{array}$ & $\begin{array}{c}\text { Patient-care } \\
\text { indicators }\end{array}$ & $\begin{array}{c}\text { Facility- } \\
\text { specific } \\
\text { indicators }\end{array}$ \\
\hline $\begin{array}{l}\text { Desalegn } \\
(2013)\end{array}$ & $\begin{array}{l}\text { Assessment of drug } \\
\text { use pattern using } \\
\text { WHO prescribing } \\
\text { indicators at Hawassa } \\
\text { University teaching } \\
\text { and referral hospital, } \\
\text { South Ethiopia: a } \\
\text { cross-sectional study }\end{array}$ & $\begin{array}{l}\text { a. The average number } \\
\text { of drugs prescribed } \\
\text { per encounter = 1.9 } \\
\text { b. The percentage of } \\
\text { encounters in which } \\
\text { an antibiotic } \\
\text { prescribed = 58.1\% } \\
\text { c. The percentage of } \\
\text { encounters in which } \\
\text { injection was } \\
\text { prescribed = 38.1\% } \\
\text { d. The Percentage of } \\
\text { drugs prescribed by } \\
\text { generic name = } \\
\text { 98.7\% } \\
\text { e. The Percentage of } \\
\text { drugs prescribed } \\
\text { from an essential } \\
\text { drug list = 96.6\% }\end{array}$ & & \\
\hline $\begin{array}{l}\text { Atif et al. } \\
(2016)\end{array}$ & $\begin{array}{l}\text { Assessment of } \\
\text { WHO/INRUD core } \\
\text { drug use indicators in } \\
\text { two tertiary care } \\
\text { hospitals of Bahawal- } \\
\text { pur, Punjab, Pakistan }\end{array}$ & $\begin{array}{l}\text { a. Average number of } \\
\text { drugs per prescript- } \\
\text { tion }=2.82 \\
\text { b. The drugs } \\
\text { prescribed by } \\
\text { generic name = } \\
56.6 \% \\
\text { c. The encounters with } \\
\text { an antibiotic pres- } \\
\text { cribed = 51.5 \% } \\
\text { d. No injections were } \\
\text { prescribed } \\
\text { e. The drugs } \\
\text { prescribed from the } \\
\text { Essential Drugs List } \\
=98.8 \%\end{array}$ & 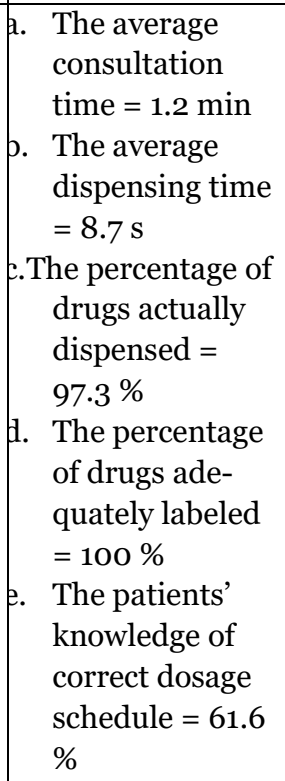 & $\begin{array}{l}\text { a. All OPDs had a } \\
\text { copy of the } \\
\text { EDL } \\
\text { b. The key drugs } \\
\text { were available } \\
\text { in stock }=72.4 \\
\%\end{array}$ \\
\hline $\begin{array}{l}\text { Gashaw et al. } \\
(2018)\end{array}$ & $\begin{array}{l}\text { Investigation of } \\
\text { prescribing behavior } \\
\text { at outpatient settings } \\
\text { of governmental hos- } \\
\text { pitals in eastern Ethi- } \\
\text { opia: an overall } \\
\text { evaluation beyond } \\
\text { World Health Organi- } \\
\text { zation core pre- } \\
\text { scribing indicators }\end{array}$ & 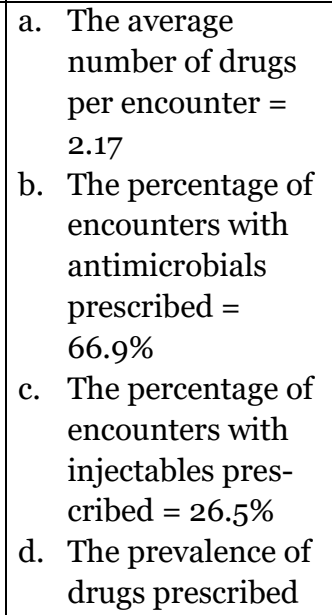 & & \\
\hline
\end{tabular}




\begin{tabular}{|c|c|c|c|c|}
\hline Author & Title & $\begin{array}{l}\text { Prescribing } \\
\text { indicators }\end{array}$ & $\begin{array}{l}\text { Patient-care } \\
\text { indicators }\end{array}$ & $\begin{array}{c}\text { Facility- } \\
\text { specific } \\
\text { indicators }\end{array}$ \\
\hline & & \begin{tabular}{|l} 
with generic name \\
$=89.01 \%$ \\
e.
\end{tabular} & & \\
\hline $\begin{array}{l}\text { Ramachandr } \\
\text { an et al. } \\
(2015)\end{array}$ & $\begin{array}{l}\text { Evaluation of pres- } \\
\text { cribing pattern of } \\
\text { anti-diabetic drugs } \\
\text { using WHO pres- } \\
\text { cribing indicators in a } \\
\text { tertiary care hospital } \\
\text { in Puducherry: A } \\
\text { cross-sectional study } \\
\text { (India) }\end{array}$ & $\begin{array}{l}\text { a. The average number } \\
\text { of drugs prescribed } \\
\text { per encounter = } 5.15 \\
\text { b. Percentages of drugs } \\
\text { prescribed by } \\
\text { generic name = } \\
25 \cdot 37 \% \\
\text { c. } \text { Percentages of anti- } \\
\text { biotic drugs = } \\
22.66 \% \\
\text { d. Percentages of } \\
\text { injections = 20.5\% } \\
\text { e. Percentages of drugs } \\
\text { prescribed from an } \\
\text { Essential Drug List } \\
\text { (EDL) = } 74.30 \%\end{array}$ & & \\
\hline $\begin{array}{l}\text { Sisay et al. } \\
(2017)\end{array}$ & $\begin{array}{l}\text { Evaluation of rational } \\
\text { drug use based on } \\
\text { World Health Organi- } \\
\text { zation core drug use } \\
\text { indicators in selected } \\
\text { public hospitals of } \\
\text { eastern Ethiopia: a } \\
\text { cross-sectional study }\end{array}$ & $\begin{array}{l}\text { a. } \text { Average drugs were } \\
\text { prescribed = 2.34 } \\
\text { b. } \text { The drugs were } \\
\text { prescribed by } \\
\text { generic name = } \\
90.61 \% \\
\text { c. } \text { The prescription } \\
\text { contained } \\
\text { antibiotics = } \\
57.87 \% . \\
\text { d. } \text { The prescription } \\
\text { contained at least } \\
\text { one injectable medi- } \\
\text { cation }=10.9 \%\end{array}$ & $\begin{array}{l}\text { a. } \begin{array}{l}\text { The average } \\
\text { consultation } \\
\text { time }=4.61 \\
\text { min }\end{array} \\
\text { b. The average } \\
\text { dispensing } \\
\text { time = 61.12 s } \\
\text { c. The } \\
\text { prescribed } \\
\text { drugs were } \\
\text { actingually } \\
\text { dispensed = } \\
\text { 75.77\% } \\
\text { d. The } \\
\text { percentage of } \\
\text { drugs ade- } \\
\text { quately } \\
\text { labeled = 3.3\% } \\
\text { e. Patients know } \\
\text { about the } \\
\text { correct dosage } \\
\text { schedule of } \\
\text { the } \\
\text { prescription = } \\
75.7 \%\end{array}$ & $\begin{array}{l}\text { a. The key } \\
\text { essential drugs } \\
\text { were available } \\
\text { in stock = } \\
66.7 \% \\
\text { b. All of the hos- } \\
\text { pitals use the } \\
\text { national EDL, } \\
\text { formulary, and } \\
\text { STGs but none } \\
\text { of them had } \\
\text { their own } \\
\text { EDLs, formu- } \\
\text { laries or STGs }\end{array}$ \\
\hline $\begin{array}{l}\text { Al-Azayzih et } \\
\text { al. (2017) }\end{array}$ & $\begin{array}{l}\text { Evaluation of drug } \\
\text { prescribing patterns } \\
\text { based on the WHO } \\
\text { prescribing indicators } \\
\text { at outpatient clinics } \\
\text { of five hospitals in }\end{array}$ & $\begin{array}{l}\text { a. The average number } \\
\text { of drugs per pres- } \\
\text { cription }=2.93 \\
\text { b. The percentage of } \\
\text { encounters which } \\
\text { had antibiotics in }\end{array}$ & & \\
\hline
\end{tabular}




\begin{tabular}{|c|c|c|c|c|}
\hline Author & Title & $\begin{array}{l}\text { Prescribing } \\
\text { indicators }\end{array}$ & $\begin{array}{c}\text { Patient-care } \\
\text { indicators }\end{array}$ & $\begin{array}{c}\text { Facility- } \\
\text { specific } \\
\text { indicators }\end{array}$ \\
\hline & $\begin{array}{l}\text { Jordan: a cross- } \\
\text { sectional study }\end{array}$ & $\begin{array}{l}\text { the prescription }= \\
17.7 \% \\
\text { c. The percentage of } \\
\text { encounters which } \\
\text { had injections in the } \\
\text { prescription = 8.1\% } \\
\text { d. The percentage of } \\
\text { prescriptions by } \\
\text { generic = 57.6\% } \\
\text { e. The prescribing } \\
\text { from the essentials } \\
\text { drug list (formulary) } \\
=99.8 \%\end{array}$ & & \\
\hline $\begin{array}{l}\text { Gidebo et al. } \\
(2016)\end{array}$ & $\begin{array}{l}\text { Assessment of drug } \\
\text { use patterns in terms } \\
\text { of the WHO patient- } \\
\text { care and facility indi- } \\
\text { cators at four } \\
\text { hospitals in Southern } \\
\text { Ethiopia: a cross- } \\
\text { sectional study }\end{array}$ & $\begin{array}{l}\text { a. Overall mean numb- } \\
\text { er of drugs } \\
\text { prescribed }=2.0\end{array}$ & $\begin{array}{l}\text { a. The mean con- } \\
\text { sultation time = } \\
4.7 \text { min } \\
\text { b.The mean dis- } \\
\text { pensing time = } \\
119.1 \mathrm{~s} \\
\text { c. The mean per- } \\
\text { centage of medi- } \\
\text { cations actually } \\
\text { dispensed = } \\
86.3 \% \\
\text { d.The mean per- } \\
\text { centage of medi- } \\
\text { cations clearly } \\
\text { labeled = 45.4\% } \\
\text { e. Patients who } \\
\text { knew their dos- } \\
\text { age forms accur- } \\
\text { ately = } 78.8 \%\end{array}$ & $\begin{array}{l}\text { a. Only one hos- } \\
\text { pital (25\%) } \\
\text { had a copy of } \\
\text { the Ethiopian } \\
\text { essential drug } \\
\text { list (EDL), } \\
\text { standard treat- } \\
\text { ment guideline } \\
\text { for hospitals } \\
\text { and drug for- } \\
\text { mulary } \\
\text { b. The mean } \\
\text { availability of } \\
\text { key drugs = } \\
65.7 \%\end{array}$ \\
\hline $\begin{array}{l}\text { Atif et al. } \\
(2017)\end{array}$ & $\begin{array}{l}\text { Investigation of anti- } \\
\text { microbial use at a } \\
\text { tertiary care hospital } \\
\text { in Southern Punjab, } \\
\text { Pakistan using WHO } \\
\text { methodology }\end{array}$ & $\begin{array}{l}\text { a. The average number } \\
\text { of antimicrobials per } \\
\text { hospitalization = } 1.4 \\
\text { b. The percentage of } \\
\text { hospitalizations with } \\
\text { antimicrobial pres- } \\
\text { cribed = 82.3\% } \\
\text { c. The percentage of } \\
\text { antimicrobial pres- } \\
\text { cribed by generic } \\
\text { names }=52.5 \%\end{array}$ & & $\begin{array}{l}\text { a. The availa- } \\
\text { bility of key } \\
\text { antimicrobial } \\
\text { drugs }=93.8 \% \\
\text { b. Hospital has a } \\
\text { formulary list } \\
\text { but the there is } \\
\text { no Standard } \\
\text { Therapy } \\
\text { Guideline } \\
\text { (STG) for } \\
\text { infectious } \\
\text { diseases. }\end{array}$ \\
\hline
\end{tabular}

\section{DISCUSSION}

Drug prescribing patterns need to be evaluated from time to time. Unwise use of drugs adds to the cost of therapy and unnecessary side effects. Medical errors in prescribing, pre- paring and administering drugs increase the potential danger of drugs in the hospital. Poor prescribing habits result in ineffective and unsafe treatment; getting worse or the length of the disease, suffering, and danger for 
the patient; and more expensive costs (Desalegn, 2013).

Some things that are considered by doctors to prescribe drugs are tolerance to the digestive tract and costeffectiveness. For example, the selection of no steroidal anti-inflammatory drugs in India, aceclofenac is preferred because it has the tolerance to the gastrointestinal tract rather than diclofenac which has a cheaper price (Vaishnavi et al., 2017). Other factors that influence doctors decisions are information provided by medical representatives and socioeconomic profiles (Varakantham et al. 2018).

From the results of a systematic review, polypharmacy occurred in all developing countries, except in Southern Ethiopia which is still acceptable as an ideal. Polypharmacy can be caused by the general practice of irrational combinations of drugs, the desire of patients to recover quickly, lack of appropriate medication therapy, unnecessary use of vitamins, aggressive drug promotion in the form of financial incentives for prescribers to prescribe more and lack of training in treatment for prescribers (Menik et al., 2011; Desalegn, 2013). Polypharmacy can cause an increased risk of drug interactions, increased hospital costs, and errors in prescribing.

Study in Sri Lanka shows the fact that it is necessary to improve the practice of good prescription, which found incomplete recipes such as no treatment duration and frequency of medication (Menik et al., 2011) and the names of patients found in Ethiopia (Gashaw et al. , 2018). This problem coupled with polypharmacy resu- lts in irrational, more expensive and unsafe prescribing.

Based on study in India, a combination of nonsteroidal antiinflammatory drugs and gastro protective agents were found in one drug that was not justified. Gastro protective agents are always consumed 30 minutes before eating because the therapeutic effectiveness decreases if consumed with food. Conversely, nonsteroidal anti-inflammatory drugs can cause side effects on the digestive tract so they are consumed after eating. The combination of no steroidal anti-inflammatory drugs with gastro protective agents is irrational because one component will be useless. The combination of paracetamol and no steroidal anti-inflammatory drugs is also not rational because it does not increase the success of treatment but can increase the cost of therapy and side effects. Paracetamol is used when antipyretic and analgesic action is needed while nonsteroidal antiinflammatory drugs are used when antipyretic, analgesic and anti-inflammatory action is needed (Vaishnavi et al. 2017). Another example of irrational prescription is a combination of paracetamol and a gastro protective agent. Paracetamol has no side effects on the digestive tract. Even it is made as a choice for patients with gastric acid disorders.

High antibiotic prescriptions still occur in Sri Lanka, India, Indonesia and Southern Ethiopia. The high percentage of antibiotics prescribed can be caused by a culture of trust regarding antibiotics, namely the patient's expectation to accept antibiotics or the doctor's belief about 
the success of antibiotics is low (Desalegn, 2013). The use of antibiotics that are less optimal occurs throughout the world, this problem is increasing in developing countries where infection rates are high but resources are limited (Atif et al., 2017). Specifically, the high percentage of antibiotics in Pakistan $(82.3 \%)$ can be caused by being an inpatient who may need more than one antibiotic.

Injection use in Sri Lanka is relatively low $(<7 \%)$. The percentage of prescriptions with high injection was found in Southern Ethiopia (38.1\%). Beliefs and attitudes of patients and health workers that the success of injections is better than oral medication and faster start time to work causes high injection use. In addition, the use of unhygienic injecttions increases the risk of transmission of potential pathogens, such as hepatitis or HIV. Therefore, drugs with oral preparations are preferred except for injection indications in emergency cases.

Several studies conducted at referral hospitals indicate that prescribing indicators are less useful for specialist outpatient clinics in referral hospitals because the pattern of drug use is more complex. Patients treated are patients with complications with serious conditions that may require more therapy.

The use of generic drugs and adherence to NLEM is a way to measure patterns of drug use rationally in prescription profiles. Generic drugs are cheaper than drugs with patent brands. The high prescription of generic drugs in Ethiopia (98.7\%) can be due to drug policies that are more ef- fective and more enforced. Variations in prescribing generic drugs between countries can be caused by differences in health care systems; doctor knowledge and experience; and health service regulations and policies (Gashaw et al., 2018).

The use of essential medicines that are in accordance with WHO recommendation in Sri Lanka (100\%) is caused by government health policies regarding the list of essential medicines that help reduce the state's health budget so as to improve the cost-effectiveness strategy (Menik et al., 2011). The high percentage of drugs prescribed from the List of Essential Medicines in Sri Lanka is also because procurement must be based on the planning that has been successfully implemented and the procurement policy. Likewise in Southern Ethiopia, almost all drugs (96.6\%) were prescribed from the Ethiopian Essential Medicine List. In Indonesia, the List of National Essential Medicines has been compiled since 1980 and is periodically revised.

A combination of treatment regimens must be adopted from the guidelines so that goals can be achieved. But the results of several studies show that adherence to clinical guidelines is not the same, varies between time and region, patient characteristics and doctor's wisdom play a large role. Variations in prescribing patterns that differ between countries can be caused by population genetic makeup. Therefore, deviations from recommendations are always expecteded (Varakantham et al., 2018).

The average consultation time in all developing countries under study 
is below the WHO recommended time, which is $\geq 10$ minutes. This is due to insufficient comparison between doctors and patients in the public sector. The time to consult with doctors at government hospitals in Sri Lanka is much shorter when compared to private practice. Comparison of doctors with the number of patients who do not fit this can also cause errors in prescribing. Insufficient consultation time results in inappropriate patient examinations and excavation of historical information and unfavorable doctor-patient relationships (Atif et al., 2016).

Short preparation time is one of the factors that causes a high risk of medication errors. The results showed that the time of preparation of the drug without the fastest waiting time was found in Pakistan (8.7 seconds). The number of patients can also be the cause of the short preparation time. Short preparation time is related to the absence of an explanation of the rules for taking medication, prevention and important clinical side effects of the drug given. Drugs, not adequately labeled can also be related to the short time of preparation of the drug. The low percentage of drugs labeled adequately in Sri Lanka (1.57\%) indicates the need for educational interventions in the practice of drug preparation. The absence of a drug name can lead to an increased incidence of adverse drug reactions or drug interactions and reduced therapeutic success.

The availability of effective drugs in the hospital results in a high percentage of the right drugs given, as happened in Sri Lanka (100\%). This improves the quality of care for patients and reduces additional costs for patients. Furthermore, it shows Sri Lanka's good national health policy to maintain the drug chain so that good health services can continue.

Good verbal communication further increases patient knowledge about the drug, in addition to adequate labeling. Health workers have an important role in providing education about drugs to patients, namely clear and safe information. Patient education must be the main pharmacist's activity to improve rational drug practices with low adverse drug reactions.

The patient's knowledge of the rules for taking medication is important because if the patient does not know about how to take medicine shows that there is no rational practice. The percentage of patients who understand the drug dose in Pakistan is $61.6 \%$. This means that as many as $38.4 \%$ of patients do not understand the drugs are given. This is compounded by inadequate labeling of drugs.

In Ethiopia, from the hospital studied, no one has a DOE or standard hospital treatment guidelines. Only one hospital in Pakistan has its own formulary but does not yet have standard treatment guidelines for infectious diseases. Because the prevalence of infectious and non-infectious diseases is influenced by weather conditions and people's lifestyles, hospitals must have their own DOE and standard treatment guidelines (Sisay et al., 2017).

Availability of important drugs in hospitals in Ethiopia is $65.7 \%$. The lack of important drugs at the hospital 
is detrimental to the patient because the doctor cannot prescribe the right medication. The absence of important drugs in stock is an indicator of weak pharmaceutical services in hospitals and disrupts the overall health services provided.

The results of this systematic review may not be representative of all developing countries because the study was only conducted in several hospitals. Besides the differences in population genetic makeup, doctor wisdom and patient characteristics also influence.

Overall, this systematic review shows variations in prescribing patterns in hospitals in several developing countries. Doctors adhere to several parameters, but non-compliance is also observed in relation to rational drug use. Evaluation of the use of this drug can be followed up with the necessary intervention. There needs to be a policy in each country to improve the quality of drug use rationally. The strategy combination is more effective than just one strategy to change the trend of drug use patterns, ranging from education, economic, managerial strategies and regulations and policies. Some activities that can be done are making standard and DOE medication guidelines; establish a drug and therapeutic committee; periodic training program for doctors and pharmacists; and the availability, access, and affordability of good standard drugs. This intervention is then reevaluated. The strategy of increasing rational drug use will ultimately improve the quality of health services in developing countries.

\begin{tabular}{l}
\hline REFERENCE \\
\hline Al-Azayzih A, Al-Azzam SI, Alzoubi \\
KH, Shawaqfeh M, Masadeh \\
MM (2017) 'Evaluation of drug- \\
prescribing patterns based on \\
the WHO prescribing indicators \\
at outpatient clinics of five hos- \\
pitals in Jordan: a cross-secti- \\
onal study', 55(5), pp. 425-433. \\
doi: 10.5414/CP202733.
\end{tabular}

Hettihewa L, Isuru A, Kalana J (2011). Prospective encounter study of the degree of adherence to patient care indicators related to drug dispensing in Health Care facilities: A Sri Lankan perspective', Journal of Pharmacy and Bioallied Sciences, 3(2), pp. 298-301.

Ramachandran G, Rohith V, Topno I (2015). Evaluation of prescribing pattern of anti-diabetic drugs using WHO prescribing indicators in a tertiary care hospital in Puducherry: A cross-sectional study', 4(5), pp. 76-80.

Sisay M, Mengistu G, Molla B, Amare F, Gabriel T (2017) 'Evaluation of rational drug use based on World Health Organization core drug use indicators in selected public hospitals of eastern Ethiopia: a cross-sectional study'. BMC Health Services Research, pp. 1-10. doi: 10.1186/s12913017-2097-3.

Varakantham V, Kurakula Sailoo AK and Bharatraj DK (2018). Antihypertensive Prescription Pattern and Compliance to JNC 7 and JNC 8 at Tertiary Care Government Hospital, Hyderabad, India: A Cross-sectional Retrospective Study. Hospital 
Pharmacy, 53(2), pp. 107-112. doi: $0.1177 / 0018578717738080$. WHO (1987). The rational use of drugs: Report of the Conference of Experts, Nairobi, 25-19 November 1985. Geneva.

WHO (1993). How to investigate drug use in health facilities. WHO. 